\title{
Strontium Isotopic Variations of Neoproterozoic Seawater: Implications for Crustal Evolution
}

\section{Citation}

Asmerom, Yemane, Stein B. Jacobsen, Andrew H. Knoll, Nicholas J. Butterfield, and Keene Swett. 1991. Strontium isotopic variations of Neoproterozoic seawater: Implications for crustal evolution. Geochimica Et Cosmochimica Acta 55, no. 10: 2883-2894.

\section{Published Version}

http://dx.doi.org/10.1016/0016-7037(91)90453-C

\section{Permanent link}

http://nrs.harvard.edu/urn-3:HUL.InstRepos:3200257

\section{Terms of Use}

This article was downloaded from Harvard University's DASH repository, and is made available under the terms and conditions applicable to Other Posted Material, as set forth at http:// nrs.harvard.edu/urn-3:HUL.InstRepos:dash.current.terms-of-use\#LAA

\section{Share Your Story}

The Harvard community has made this article openly available.

Please share how this access benefits you. Submit a story.

\section{Accessibility}




\title{
Strontium isotopic variations of Neoproterozoic seawater: Implications for crustal evolution
}

\author{
Yemane Asmerom, ${ }^{1}$ Stein B. JaCobsen, ${ }^{1}$ Andrew H. KNOll, ${ }^{2}$ NiCholas J. ButTerfield, ${ }^{2}$ and Keene SwetT ${ }^{3}$ \\ ${ }^{1}$ Harvard Center for Isotope Geochemistry, Department of Earth and Planetary Sciences, Harvard University, Cambridge, MA 02138, USA \\ ${ }^{2}$ Department of Organismic and Evolutionary Biology, Harvard University, Cambridge, MA 02138, USA \\ ${ }^{3}$ Department of Geology, University of Iowa, Iowa City, IA 52242, USA
}

(Received March 26, 1991; accepted in revised form July 19, 1991)

\begin{abstract}
We report high precision Sr isotopic data on carbonates from the Neoproterozoic Shaler Group, Victoria Island, Northwest Territories, Canada. Lithostratigraphic correlations with the relatively welldated Mackenzie Mountains Supergroup constrain Shaler deposition to $\sim 770-880 \mathrm{Ma}$, a range corroborated by $723 \pm 3 \mathrm{Ma}$ lavas that disconformably overlie Shaler carbonates and by Late Riphean microfossils within the section.

Samples with low ${ }^{87} \mathrm{Rb} /{ }^{86} \mathrm{Sr}$ ratios $(<0.01)$ were selected for $\mathrm{Sr}$ isotopic analysis. $\delta^{18} \mathrm{O}, \mathrm{Mn}, \mathrm{Ca}, \mathrm{Mg}$, and $\mathrm{Sr}$ data were used to recognize altered samples. The altered samples are characterized by high $\mathrm{Mn} /$ $\mathrm{Sr}(\geq 2)$ and variable $\delta{ }^{18} \mathrm{O}$; most are dolomites. The data indicate that between ca. $790-850 \mathrm{Ma}$ the ${ }^{87} \mathrm{Sr} /$ ${ }^{86} \mathrm{Sr}$ ratio of seawater varied between 0.70676 and 0.70561 . The samples show smooth and systematic variation, with the lowest ${ }^{87} \mathrm{Sr} /{ }^{86} \mathrm{Sr}$ value of 0.70561 at ca. $830 \mathrm{Ma}$. The low ${ }^{87} \mathrm{Sr} /{ }^{86} \mathrm{Sr}$ ratio of carbonates from the lower parts of our section is similar to a value reported for one sample from the Adrar of Mauritania ( $\approx 900 \mathrm{Ma}$ ), West African Craton. Isotopic ratios from the upper part of the Shaler section are identical to values from the lower part of the Neoproterozoic Akademikerbreen Group, Spitsbergen. Although a paucity of absolute age determinations hinders attempts at the precise correlation of Neoproterozoic successions, it is possible to draw a broad outline of the $\mathrm{Sr}$ isotopic composition of seawater for this period. Indeed, the $\mathrm{Sr}$ isotope data themselves provide a stratigraphic tool of considerable potential.

Data from this study and the literature are used to construct a curve of the ${ }^{87} \mathrm{Sr} /{ }^{86} \mathrm{Sr}$ ratio of Neoproterozoic seawater. The new data reported in this study substantially improve the isotopic record of $\mathrm{Sr}$ in seawater for the period 790-850 Ma. The $\mathrm{Sr}$ isotope composition of seawater reflects primarily the balance between continental $\mathrm{Sr}$ input through river input and mantle input via hydrothermal circulation of seawater through mid-ocean ridges. Coupling of $\mathrm{Nd}$ and $\mathrm{Sr}$ isotopic systems allows us to model changes in seafloor spreading rates (or hydrothermal flux) and continental erosion. The Sr hydrothermal flux and the erosion rate (relative to present-day value) are modeled for the period 500-900 $\mathrm{Ma}$. The results indicate that the hydrothermal flux reached a maximum value at ca. $830 \mathrm{Ma}$. In contrast, a large peak in erosion rate is indicated at ca. $570 \mathrm{Ma}$. The peaks in hydrothermal flux and erosion rate are most likely related to developments in the Pan-African and related orogenic events, whose initial development is characterized by production of juvenile crust during supercontinental break up and rifting. The time ca. $570 \mathrm{Ma}$ is characterized by continent-continent collision and production of recycled crust. Sr isotope data from Proterozoic carbonates offer a valuable resource for understanding large-scale crust dynamics.
\end{abstract}

\section{INTRODUCTION}

OUR KNOWLEDGE OF crustal evolution in the Neoproterozoic $(540-1000 \mathrm{Ma})$ is fragmentary at best, but the ${ }^{87} \mathrm{Sr} /{ }^{86} \mathrm{Sr}$ record in marine carbonates offers a potentially powerful tool in tracing large-scale crustal processes during this period. Strontium has a long residence time in the ocean, about $4 \mathrm{Ma}$; thus, the $\mathrm{Sr}$ isotope composition of seawater at any time is uniform to within present-day analytical precision. The $\mathrm{Sr}$ isotope composition of seawater reflects primarily the balance between continental river input and mantle input as a result of the interaction of seawater with ocean crust during hydrothermal circulation through mid-ocean ridges. The $\mathrm{Sr}$ isotope composition of marine carbonates, thus, records the balance between these two contributions through time. $\mathrm{JA}_{\mathrm{A}}$ COBSEN (1988) suggested that this may be used to recognize three major episodes of high global erosion rates corresponding to major continental collisions during the past $600 \mathrm{Ma}$. Insofar as the relative contributions of the continental crust and the mantle are affected by tectonic processes and crust- mantle dynamics, the carbonate ${ }^{87} \mathrm{Sr} /{ }^{86} \mathrm{Sr}$ record provides a resource for studying these processes through Earth history.

The ${ }^{87} \mathrm{Sr} /{ }^{86} \mathrm{Sr}$ values of ancient seawater are known to within 0.00005 for the Cenozoic Era (DEPAOLO and INGRAM, 1985; PALMER and ElderFIELD, 1985; DEPAOLO, 1986; HeSS et al., 1986; HoDELL et al., 1989; KOEPNICK et al., 1988) and to within ca. 0.0002 for the Mesozoic and Paleozoic (BURKE et al., 1982; KOEPNICK et al., 1985, 1990). The Neoproterozoic record is far less well established, but an improving data base confirms that this was an interval of extreme secular variation. DERRY et al. (1989) recently reportcd a new curve for the time period between $650 \mathrm{Ma}$ and $800 \mathrm{Ma}$, finding relatively low and uniform values of about 0.707 . At the end of the Proterozoic (between 610-550 Ma), seawater $\mathrm{Sr}$ isotopic ratio rose rapidly to values of ca. 0.709 (VEIZER et al., 1983; SHAW and WASSERBURG, 1985; BURKE et al., 1982). This rise is comparable in magnitude to that recorded in marine carbonates from the Cretaceous to present.

In any study of seawater $\mathrm{Sr}$ isotopic variations, resolution is limited by stratigraphy. The problem is particularly acute 
for Proterozoic basins, where stratigraphic correlation is often hampered by a paucity of both radiometric ages and index fossils (although biostratigraphic control is improving rapidly for at least the Neoproterozoic; cf. KNOLL and BUTTERFIELD, 1989). As discussed by DERRY et al. (1989), analysis of sample suites collected from measurcd sections within a single basin provides potentially fine stratigraphic resolution for the time interval represented by the section. Given constraining radiometric data, age estimates can be assigned to samples by utilizing empirical basin subsidence models. Correlation among basins is constrained by absolute dates and fossils, as well as by the ${ }^{87} \mathrm{Sr} /{ }^{86} \mathrm{Sr}$ patterns themselves. Thus, despite, stratigraphic limitations, broad patterns of secular variation in the ${ }^{87} \mathrm{Sr} /{ }^{86} \mathrm{Sr}$ - ratio of Proterozoic seawater can be recognized, and these can be utilized in understanding large-scale geologic processes.

In this paper, we report new data from carbonates of the Shaler Group, Victoria Island, Northwest Territories, Canada (YouNG, 1981). These are the first stratigraphically coherent ${ }^{87} \mathrm{Sr} /{ }^{86} \mathrm{Sr}$ data for seawater for the period $790-850 \mathrm{Ma}$. Data from the older part of the section are particularly important because of the indication of VEIZER et al. (1983) of extremely low seawater ${ }^{87} \mathrm{Sr} /{ }^{86} \mathrm{Sr}$ at ca. $900 \mathrm{Ma}$. They suggested that this may record a significant global event. We also present a ${ }^{87} \mathrm{Sr} /{ }^{86} \mathrm{Sr}$ curve for the period $500-900 \mathrm{Ma}$ and evaluate crustmantle evolution during this time by coupling $\mathrm{Sr}$ and $\mathrm{Nd}$ isotopic curves for seawater. In the present study, we have utilized a combination of isotopic and elemental data to select the least-altered 17 samples reported here from a set of 39 limestones and dolomites.

\section{SAMPLES AND STRATIGRAPHY}

\section{Geological Setting and Stratigraphy}

The Shaler Group is a nearly $4000 \mathrm{~m}$ thick package of Neoproterozoic sedimentary rocks exposed in the Minto Arch, a southwestto-northeast trending highland in western Victoria Island, Canadian Arctic Archipelago. Along with preserved outliers in southern Victoria Island, neighboring Banks Island, and the Brock Inlier and Copperminc area of the mainland Northwest Territorics, Shalcr rocks formed part of the sedimentary infilling of a broad region of Neoproterozoic subsidence known as the Amundsen Embayment (YouNG, 1981). Although uplifted and intruded by numerous sills, Shaler rocks remain nearly flat lying and, except for the contact aureoles surrounding intrusions, they are essentially unmetamorphosed. The stratigraphy and sedimentology of the Shaler Group have been detailed in a series of papers by Grant Young and his coworkers, and the following summary is taken from these accounts (YOUNG, 1981 and papers cited therein), as well as from our own measured sections. The stratigraphy of this group is shown schematically in Fig. 1.

Shaler rocks have been divided lithostratigraphically into five formations. The basal unit, the Glenelg Formation, consists of a ca. 600 $m$ thick succession of deltaic to shallow marine sandstones and shales (DIXON, 1979) overlain by a nearly comparable thickness of peritidal dolomites and limestones (YOUNG and JEFFERSON, 1975; JEFFERSON, 1977). Above this is a deltaic sequence of siliciclastic rocks capped by carbonates containing a distinctive stromatolitic hiostrome (YOUNG and LONG, 1977; JEFFERSON, 1977). The formation has a total thickness of some $1400 \mathrm{~m}$ (YOUNG, 1981); field circumstances permitted detailed sampling only from the upper carbonates of the Glenelg Formation.

The overlying Reynolds Point Formation is nearly $1000 \mathrm{~m}$ thick. It begins with a recurrence of deltaic to shallow marine siliciclastic rocks, but consists principally of shallow subtidal to intertidal marine limestones and subordinate dolomites (YOUNG and LONG, 1977). Lithologies include bedded micrites, oolitic grainstones, and subor- dinate stromatolites. Reynolds Point carbonates are overlain abruptly by the interbedded evaporites and dolomites of the Minto Inlet Formation (YoUNG, 1981). Some $200 \mathrm{~m}$ thick, this formation records restricted coastal environments in a semi-arid region. Restoration of less restricted peritidal to subtidal shelf or platform conditions is indicated by the micrites, oolitic, and intraclastic grainstones, oncolites, and stromatolites of the Wynniatt Formation, minimally $\mathbf{4 0 0}$ $m$ thick in an incompletely exposed section measured by YOUNG (1981), and reportedly up to $900 \mathrm{~m}$ thick elsewhere (YouNG, 1981). The Shaler succession is capped by $400-500 \mathrm{~m}$ of carbonates, red beds, and evaporites belonging to the Kilian Formation (YouNG, 1981). Our collections include only reconnaissance samples from the Kilian Formation.

\section{Samples}

It is commonly assumed that, given their age and associated likelihood of metamorphism, Proterozoic sedimentary rocks should be relatively poor candidates for $\mathrm{Sr}$ isotopic geochemical study; however, for Neoproterozoic carbonates, at least, we argue the reverse-namely, that these rocks are as good as or possibly even better subjects for analysis than many Phanerozoic limestones. First, the rocks under consideration here, as well as many other Neoproterozoic successions, are little affected by orogenesis and metamorphism. Their maximum burial temperatures (as inferred from the color of organic matter in contained microfossils) are no greater than those routinely encountered in Paleozoic carbonates. Second, most of the samples under consideration here are fine-grained micrites and stromatolites of low initial porosity.

There is abundant evidence of very early diagenetic cementation from porewaters whose chemical composition approximated that of seawater (see KNOLL and SWETT, 1990). Thus, carbonates were commonly mincralogically stabilized and filled by porosity-occluding cement prior to deep burial. Added to this, many of Neoproterozoic carbonates originated as aragonite and still contain more than 1000 ppm Sr (e.g., TUCKER, 1982; SWETT and KNOLL, 1989; DERRY et al., 1989; GRANT et al., 1991). In combination, all of these factors suggest that when care is taken in sample selection (see below) the present $\mathrm{Sr}$ isotopic composition of the samples under study may provide a meaningful approximation of Neoproterozoic seawater composition. Support for this position comes from the relatively smooth trend of isotopic ratios in stratigraphically contiguous samples, as well as the unusually low ${ }^{87} \mathrm{Sr} /{ }^{86} \mathrm{Sr}$ values for this succession-generally diagenesis moves the $\mathrm{Sr}$ isotopic composition toward higher values.

Individual sample descriptions are given in Table 1. Samples with visible veining and alteration were avoided. Most of the samples are limestones, except for three dolomites.

\section{Ages of the Samples}

Depositional ages for the Shaler Group are constrained in a general way by available radiometric dates. The group lies unconformably above rocks containing ca. 1.2 Ga old lavas (WANLESS and LovERIDGE, 1972) and disconformably beneath basaltic lavas recently dated by U-Pb on baddeleyite as $723 \pm 3$ Ma (HEAMAN and RAINBIRD, 1990). Additional constraints may be inferred from widely accepted lithostratigraphic correlations between the Shaler Group and better dated successions exposed in the Mackenzie Mountains, some $800 \mathrm{~km}$ to the southwest (YOUNG et al., 1979; JEFFERSON, 1985). The lower Kilian and older Shaler formations correlate with the Mackenzie Mountains Supergroup in the Mackenzie Mountains. Paleomagnetic constraints indicate that the Mackenzie Mountains Supergroup is younger than ca. $880 \mathrm{Ma}$ (PARK and AITKEN, 1986), while ages on diabase sheets indicate that it is older than $766 \pm 24$ Ma (ARMSTRONG et al., 1982). The Mackenzie Mountains Supergroup is overlain unconformably by red beds, carbonates, and evaporites of the Coates Lake Group (JEFFERSON, 1977; AITKEN, 1981); although there have been several suggestions of how Shaler rocks correlate with specific units in the Coates Lake Group, it appears clear that at least the upper part of the Kilian Formation belongs to this sedimentary package rather than the underlying Mackenzie Mountains package (JEFFERSON, 1985). Thus, the Shaler Group rocks 

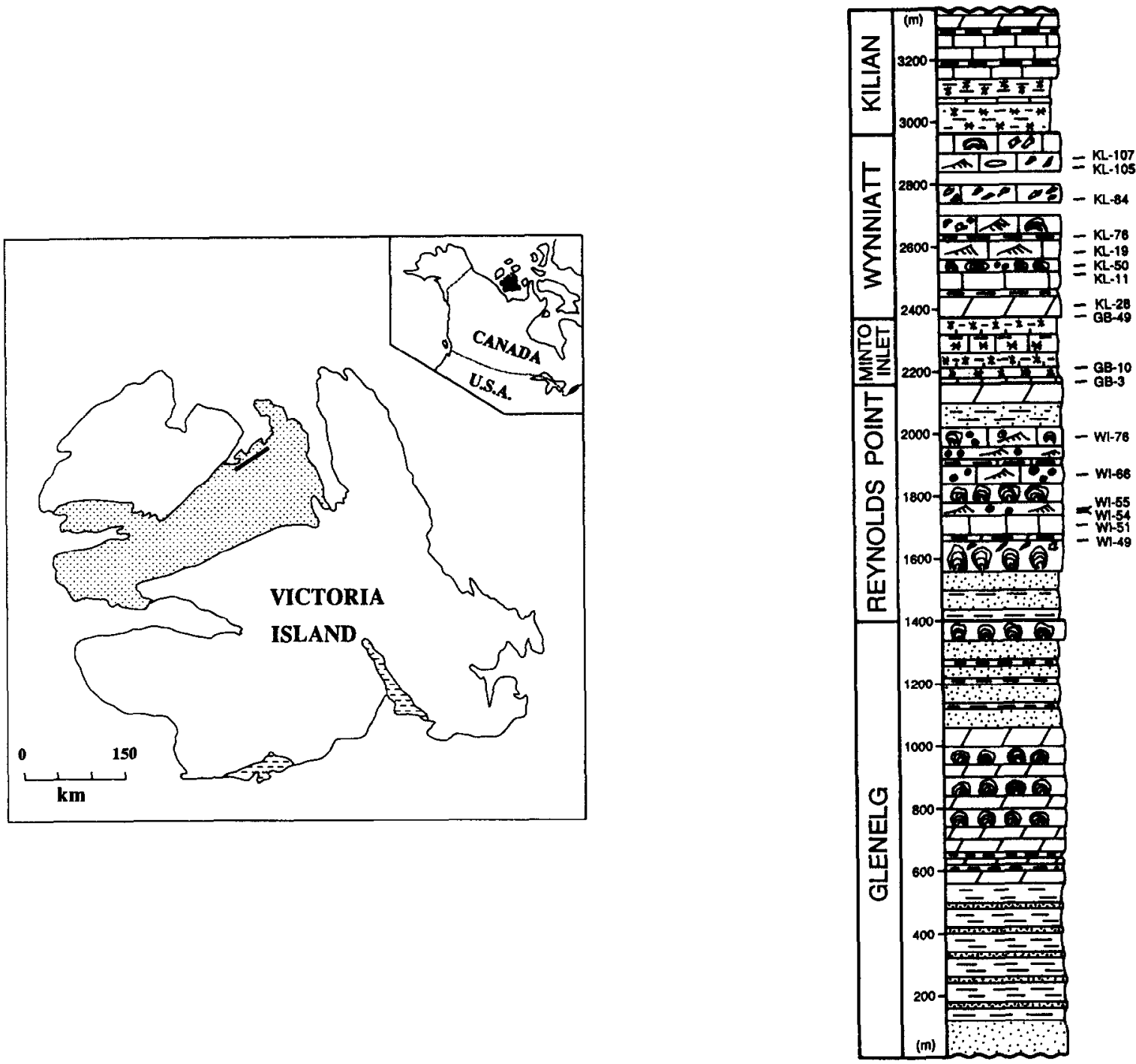

FIG. 1. Location map and generalized stratigraphy of the Shaler Group, Victoria Island. Dotted pattern in the map shows the Shaler Group sediments (sample collection area is shown by the bar). The dashed pattern shows other Proterozoic sediments.

from which our isotopic measurements come appear to have been deposited beginning sometime after $880 \mathrm{Ma}$ and ending ca. $790 \mathrm{Ma}$ ago. Planktonic microfossils in Wynniatt shales independently suggest a Late Riphean age of deposition (BUTTERFIELD and RAINBIRD, 1988, and unpublished data).

It is desirable to have absolute ages for individual samples. In the absence of absolute age information within the section, we chose to assign relative ages based on a basin subsidence model (cf. DERRY et al., 1989). SLEEP (1971) found that sedimentation rates from modern continental margins decay exponentially with time, $t$, and thus the rate of sedimentation is $A(t)=A_{0} e^{-t / r_{e}}$, where $A_{0}$ is the initial sedimentation rate, and $\tau_{e}$ is the erosion rate time constant. It follows that the age of a given sample may be calculated as a function of its stratigraphic height $D$, measured from the base of the section by

$$
T=T_{0}+\tau_{\mathrm{e}} \ln \left[1-\frac{D}{\tau_{\mathrm{e}} A_{\mathbf{0}}}\right],
$$

where $T_{0}$ is the age of the oldest sediments at the base of the section (in this case $=880 \mathrm{Ma}$ ) and $T$ is the age of a given horizon. Our calculated ages assume sedimentation from an initial age $T_{0}=880$ $\mathrm{Ma}$ at the base of the Glenelg Formation to a final age of $723 \mathrm{Ma}$ at the top of the Kilian Formation. To calculate ages for the samples from Eq. (1), we used a 157 Ma duration of sedimentation, $3360 \mathrm{~m}$ for the thickness of the section. A value of $\tau_{\mathrm{e}}=50 \mathrm{Ma}$ fits many passive margins (SLEEP, 1971), and if $D(723 \mathrm{Ma})=3360 \mathrm{~m}$, this yields $A_{0}=70.24 \mathrm{~m} \mathrm{Ma}^{-1}$. We obtain an age of $767 \mathrm{Ma}$ for the middle of the Kilian Formation. This age is identical to the age of $766 \mathrm{Ma}$, inferred from the correlation with the top of the Mackenzie Mountains Supergroup.

A number of assumptions have been made in this approach:

1) The sedimentary package, from the base of the Glenelg Formation to the top of the Kilian, was deposited in one cycle of sedimentation.

2) There are no major stratigraphic breaks within the sedimentary package. This may well be violated within the Kilian Formation, but appears to be broadly applicable for the bulk of the group (YOUNG, 1981).

3) The Shaler basin was analogous to modern continental margins.

4) Finaily, we assume that the upper and lower depositional ages are well fixed.

As discussed earlier, the absolute age uncertainties are in reality likely to be larger than the uncertainties in relative ages of individual sam- 
Table 1. Sample descriptions and ages.

\begin{tabular}{|c|c|c|c|}
\hline Sample & Lithology & Height $^{\dagger}$ & $\operatorname{Age}(\mathrm{Ma})^{\ddagger}$ \\
\hline \multicolumn{2}{|c|}{ I. Kilian Formation (400 m thick) } & 3360 & 723 \\
\hline \multicolumn{2}{|c|}{ II. Wynniatt Formation (590 m thick) } & 2960 & 787 \\
\hline $\begin{array}{l}\text { KL-107 } \\
\text { KL-105 }\end{array}$ & $\begin{array}{l}\text { laminated microspar (lst) } \\
\text { cryptalgal microspar (lst) }\end{array}$ & $\begin{array}{l}2879 \\
2854\end{array}$ & $\begin{array}{l}794 \\
796\end{array}$ \\
\hline $\begin{array}{l}\mathrm{KL-84} \\
\mathrm{KL}-76\end{array}$ & $\begin{array}{l}\text { laminated microspar (1st); } \\
\text { stylolites, interbedded chert }\end{array}$ & 2754 & 803 \\
\hline RL- 10 & $\begin{array}{l}\text { micrite clasts } \\
\text { mate }\end{array}$ & 2629 & 811 \\
\hline KL-19 & microspar (lst) & 2578 & 814 \\
\hline KL-50 & oosparite (lst) & 2530 & 816 \\
\hline $\mathrm{KL}-11$ & microspar (lst) & 2513 & 817 \\
\hline KL-28 & $\begin{array}{l}\text { microspar (lst); poorly laminated, } \\
\text { synerisis }\end{array}$ & 2406 & 822 \\
\hline GB-49 & laminated microspar (dol) & 2373 & 824 \\
\hline \multicolumn{2}{|c|}{ III. Minto Inlet Formation (210 m thick) } & 2370 & 824 \\
\hline $\begin{array}{l}\text { GB-10 } \\
\text { GB-3 }\end{array}$ & $\begin{array}{l}\text { laminated microspar (lst) } \\
\text { laminated micrite (dol) }\end{array}$ & $\begin{array}{l}2206 \\
2158\end{array}$ & $\begin{array}{l}831 \\
832\end{array}$ \\
\hline \multicolumn{2}{|c|}{$I V$. Reynolds Point Formation ( $760 \mathrm{~m}$ thick) } & 2160 & 832 \\
\hline $\begin{array}{l}\text { WI-76 } \\
\text { WI-66 } \\
\text { WI-55 } \\
\text { WI-54 } \\
\text { WI-51 }\end{array}$ & $\begin{array}{l}\text { oosparite (lst) } \\
\text { laminated microspar (lst) } \\
\text { peloidal oolite (lst) } \\
\text { calcisiltite; cross-bedded }\end{array}$ & $\begin{array}{l}1992 \\
1870 \\
1761 \\
1749\end{array}$ & $\begin{array}{l}838 \\
842 \\
845 \\
846\end{array}$ \\
\hline $\begin{array}{l}\text { WI-51 } \\
\text { WI-49 }\end{array}$ & $\begin{array}{l}\text { cryptalgal-stromatolitic } \\
\text { microspar (lst) } \\
\text { stromatolitic microspar (dol) }\end{array}$ & $\begin{array}{l}1707 \\
1658\end{array}$ & $\begin{array}{l}847 \\
848\end{array}$ \\
\hline \multicolumn{2}{|c|}{ V. Glenelg Formation ( $1400 \mathrm{~m}$ thick) } & $\begin{array}{l}1400 \\
0\end{array}$ & $\begin{array}{l}855 \\
880\end{array}$ \\
\hline
\end{tabular}

$\dagger$ ) All heights (in meters) are referenced to a zero point at the base of the Glenelg Formation.

†) The ages for the samples are calculated assuming $\mathrm{T}_{0}=880 \mathrm{Ma}$ for the base of the Glenelg Formation and $723 \mathrm{Ma}$ for the top of the Kilian Formation by using the subsidence model discussed in the text. The ages of the individual samples are given by $T(M a)=T_{0}+50 \ln [1-0.0002847 \cdot D]$ where $D$ is the height above the base of the Glenelg Formation.

ples. The calculated ages for the Victoria Island samples are given in Table 1.

\section{ANALYTICAL PROCEDURES}

Fresh chips of carbonate rock samples were ground to a fine powder in a clean stainless steel mortar. About $20 \mathrm{mg}$ of each sample were dissolved in $0.5 \mathrm{M}$ acetic acid for the $\mathrm{Rb}-\mathrm{Sr}$ isotopic work. The residue was dried and weighed to determine the percentage dissolution, which was typically about $90 \%$. An aliquot of the clear solution was spiked with a mixed ${ }^{87} \mathrm{Rb}^{84} \mathrm{Sr}$ tracer. $\mathrm{Rb}$ and $\mathrm{Sr}$ concentrations were measured on a VG-54 single-collector mass spectrometer. ${ }^{87} \mathrm{Sr} /{ }^{86} \mathrm{Sr}$ ratios were determined on a Finnigan MAT 262 9-collector mass spectrometer. $\mathrm{Rb}$ interference was monitored with an ion counting system. The NBS-987 Sr standard was run with every batch yielding a cumulative mean ${ }^{87} \mathrm{Sr} /{ }^{86} \mathrm{Sr}$ ratio of $0.710241 \pm 8$ during the course of the study. In addition for modern seawater $\mathrm{Sr}$ we obtained an average value of ${ }^{87} \mathrm{Sr} /{ }^{86} \mathrm{Sr}=0.709174 \pm 5$. Chemical separation of $\mathrm{Rb}$ and Sr was performed with cation exchange chemistry using $2 \mathrm{~N} \mathrm{HCl}$. The total procedural blanks of $20 \mathrm{pg}$ for $\mathrm{Rb}$ and $60 \mathrm{pg}$ for $\mathrm{Sr}$ have negligible influence on the results for the samples.

Using the same rock powders, about $20 \mathrm{mg}$ of each sample were dissolved in $0.5 \mathrm{M}$ acetic acid for major and trace element determination. The clear solution was diluted with $0.5 \mathrm{~N} \mathrm{HNO}_{3}$ and spiked with ${ }^{115} \mathrm{In}$. $\mathrm{Ca}, \mathrm{Mg}, \mathrm{Sr}$, and $\mathrm{Mn}$ were determined on a VG-PQ2+ inductively coupled plasma mass spectrometer. Multiple isotopes were used for the determination of each element if possible; this was particularly important for $\mathrm{Ca}$, due to the large Ar peak at mass 40 . Results from ${ }^{42} \mathrm{Ca}$ and ${ }^{48} \mathrm{Ca}$ were in good agreement. Single element standards with variable concentrations, prepared from SPEX-1000 ppm ICP-MS standards and cross-calibrated with in-house standards, were run with every batch of sample. Analytical precision for all elements is estimated at or better than $2 \%$.

$\mathrm{C}$ and $\mathrm{O}$ isotope measurements were obtained from determination of $\mathrm{CO}_{2}$ isotope ratios on a VG Prism triple collector mass spectrometer. The $\mathrm{CO}_{2}$ gas was obtained by reacting about $1 \mathrm{mg}$ of sample with $\mathrm{H}_{3} \mathrm{PO}_{4}\left(\rho \geq 1.89 \mathrm{~g} \mathrm{~mL}^{-1}\right)$ at $90^{\circ} \mathrm{C}$ in a carbonate auto-sampling system (ISOCARB) attached to the mass spectrometer. The isotopic composition of $\mathrm{C}$ and $\mathrm{O}$ is reported as per mil deviations ( $\delta$-values) relative to the PDB standard.

\section{Data Representation}

Various conventions have been utilized in reporting $\mathrm{Sr}$ isotopic data of carbonates. The uniformity of the $\mathrm{Sr}$ isotope composition of present-day seawater makes it possible to avoid interlaboratory measurement-related bias by reporting the measured ${ }^{87} \mathrm{Sr} /{ }^{86} \mathrm{Sr}$ ratios of a sample as well as the measured ${ }^{87} \mathrm{Sr} /{ }^{86} \mathrm{Sr}$ ratio of modern seawater (PAPANASTASSIOU and Wasserburg, 1969). In a previous paper from this laboratory (DERRY et al., 1989) the initial ${ }^{87} \mathrm{Sr} /{ }^{86} \mathrm{Sr}$ isotopic ratios of ancient seawater $\left[\left({ }^{87} \mathrm{Sr} /{ }^{86} \mathrm{Sr}\right)_{1}\right]$ were reported relative to modern seawater using the convention of HESS et al., (1986):

$$
\delta^{87} \mathrm{Sr}=\left[\frac{\left({ }^{87} \mathrm{Sr} /{ }^{86} \mathrm{Sr}\right)_{\mathrm{I}}}{\left({ }^{87} \mathrm{Sr} /{ }^{86} \mathrm{Sr}\right)_{\mathrm{SW}}^{0}}-1\right] \cdot 10^{5}
$$

where $\left({ }^{87} \mathrm{Sr} /{ }^{86} \mathrm{Sr}\right){ }_{\mathrm{Sw}}^{0}$ is the value of modern seawater $(0.709174$ is the value measured in this laboratory $)$ and $\left({ }^{87} \mathrm{Sr} /{ }^{86} \mathrm{Sr}\right)$ is the calculated 
${ }^{87} \mathrm{Sr} /{ }^{86} \mathrm{Sr}$ value of the sample at the time of deposition. It now appears that most data are being reported using the convention of DEPAOLO and INGRAM (1985; cf. KOEPNICK et al., 1990):

$$
\Delta_{\mathrm{SW}}=\left[\left({ }^{87} \mathrm{Sr} /{ }^{86} \mathrm{Sr}\right)_{\mathrm{I}}-\left({ }^{87} \mathrm{Sr} /{ }^{86} \mathrm{Sr}\right)_{\mathrm{SW}}^{0}\right] \cdot 10^{5} .
$$

While there is a simple relationship $\left(\Delta_{\mathrm{SW}}=\left({ }^{87} \mathrm{Sr} /{ }^{86} \mathrm{Sr}\right){ }_{\mathrm{Sw}}^{0} \delta^{87} \mathrm{Sr}\right)$ between these two conventions we have decided to report calculated initial ${ }^{87} \mathrm{Sr} /{ }^{86} \mathrm{Sr}$ ratios along with $\Delta_{\mathrm{Sw}}$-values (Table 2).

For modeling, initial ${ }^{87} \mathrm{Sr} /{ }^{86} \mathrm{Sr}$ are best represented as $\epsilon_{\mathrm{Sr}}(T)$ values defined by

$$
\epsilon_{\mathrm{SI}}(T)=\left[\frac{\left({ }^{87} \mathrm{Sr} /{ }^{86} \mathrm{Sr}\right)_{\mathrm{I}}}{\left({ }^{87} \mathrm{Sr} /{ }^{86} \mathrm{Sr}\right)_{\mathrm{UR}}^{T}}-1\right] \cdot 10^{4}
$$

where $\left({ }^{87} \mathrm{Sr} /{ }^{86} \mathrm{Sr}\right){ }_{\mathrm{UR}}^{T}$ is the isotopic composition of the bulk Earth at the time of sample deposition, $T$. This value is calculated using $\left.\left({ }^{87} \mathrm{Sr} /{ }^{86} \mathrm{Sr}\right)\right)_{\mathrm{UR}}^{0}=0.7045$ and $\left({ }^{87} \mathrm{Rb} /{ }^{86} \mathrm{Sr}\right){ }_{\mathrm{UR}}^{0}=0.0827$ (DEPAOLO and WASSERBURG, 1977). It follows that

$$
\epsilon_{\mathrm{Sr}}(T) \approx \frac{0.1 \Delta_{\mathrm{Sw}}}{\left({ }^{87} \mathrm{Sr} /{ }^{86} \mathrm{Sr}\right)_{\mathrm{Sw}}^{0}}+\epsilon_{\mathrm{Sr}}(0)+Q_{\mathrm{sr}} T
$$

where $\epsilon_{\mathrm{Sr}}(0) \approx+66.34$ (modern seawater) and $Q_{\mathrm{Sr}}=10^{4} \lambda_{\mathrm{Rb}}$ $\times\left({ }^{87} \mathrm{Rb} /{ }^{87} \mathrm{Sr}\right)_{\mathrm{UR}}^{0}=16.7 \mathrm{Ga}^{-1}$, where $\lambda_{\mathrm{Rb}}=0.0142 \mathrm{Ga}^{-1}$ is the decay constant of ${ }^{87} \mathrm{Rb}$. Thus, the correction necessary to properly compare a sample with an $800 \mathrm{Ma}$ stratigraphic age to a modern value is $\approx 13.4$ €-units.

\section{RESULTS}

\section{Elemental and Isotopic Systematics}

Strontium, oxygen, and carbon isotopic composition and elemental data are given in Table 2 . Of 39 samples ( 10 dolomites and 29 limestones) we found 18 with ${ }^{87} \mathrm{Rb} /{ }^{86} \mathrm{Sr}$ $\leq 0.01$ and used 17 of these ( 3 dolomites and 14 limestones) for further investigation. Thus, for these 17 samples the maximum correction to ${ }^{87} \mathrm{Sr} /{ }^{86} \mathrm{Sr}$ due to decay of ${ }^{87} \mathrm{Rb}$ is 0.0001 . The limestones have Sr concentrations of $100-500 \mathrm{ppm}$ while the dolomites have $30-60 \mathrm{ppm}$.

We believe that by selecting samples with low $\mathrm{Rb} / \mathrm{Sr}$ ratios, we eliminate most of the altered samples. However, it is possible that the ${ }^{87} \mathrm{Sr} /{ }^{86} \mathrm{Sr}$ ratio of carbonate may be altered without an appreciable rise in its $\mathrm{Rb} / \mathrm{Sr}$ ratio. The alteration of the ${ }^{87} \mathrm{Sr} /{ }^{86} \mathrm{Sr}$ ratio in carbonate rocks may take place during burial diagenesis as a result of exchange with fluids that have different $\mathrm{Sr}$ isotope composition. It is also possible to leach $\mathrm{Sr}$ from a noncarbonate domain during sample preparation. We used weak acetic acid $(0.5 \mathrm{M})$ to minimize this effect. In contrast most previously published work on ${ }^{87} \mathrm{Sr} /{ }^{86} \mathrm{Sr}$ in carbonates used $\mathrm{HCl}$ for dissolution.

In addition to selecting samples with low $\mathrm{Rb} / \mathrm{Sr}$ ratios, we investigated the elemental and stable isotope systematics in order to further eliminate altered samples. BRAND and VEIZER (1980) found that altered carbonates have higher $\mathrm{Mn} / \mathrm{Sr}$ ratios than unaltered ones as a result of the strong partitioning of $\mathrm{Mn}$ into the carbonate phase during carbonatefluid interaction. The three dolomites (open squares in Fig. 2) all have higher $\mathrm{Mn} / \mathrm{Sr}$ ratios, as well as higher $\mathrm{Ca} / \mathrm{Sr}$ ratios than the limestones (solid and open circles in Fig. 2). The limestones show a relatively limited range of $\mathrm{Mn} / \mathrm{Sr}$ and $\mathrm{Ca} /$ $\mathrm{Sr}$ ratios (Fig. 2b) typical of fairly unaltered carbonate rocks. It is clear from this that the dolomites are not desirable for the determination of seawater $\mathrm{Sr}$ isotope composition.

Table 2. Analytical Data and Initial Values for Victoria Island Carbonates.

$\begin{array}{lllllllllllll}\text { Sample } & \mathrm{Rb}^{*} & \mathrm{Sr}^{*} & {\left[\frac{87 \mathrm{~Kb}}{86 \mathrm{Sr}}\right]} & {\left[\frac{87 \mathrm{Sr}}{86 \mathrm{Sr}}\right]^{* *}} & {\left[\frac{87 \mathrm{Sr}}{86 \mathrm{Sr}}\right]_{\mathrm{I}}} & \Delta_{\mathrm{SW}}{ }^{*} & \delta^{13} \mathrm{C}_{\dagger \dagger}^{\dagger} & \delta^{18 \mathrm{O} \dagger \dagger} & \mathrm{Mn} / \mathrm{Sr} & \mathrm{Ca} / \mathrm{Sr} & \mathrm{Mg} / \mathrm{Ca}\end{array}$

\section{Wynniatt Formation}

$\begin{array}{llll}\text { KL-107 } & 0.565 & 251.9 & 0.0064 \\ \text { KL-105 } & 0.897 & 520.3 & 0.0050 \\ \text { KL-84 } & 0.006 & 150.3 & 0.0010 \\ \text { KL-76 } & 0.093 & 202.7 & 0.0013 \\ \text { KL-19 } & 0.281 & 201.8 & 0.0040 \\ \text { KL-50 } & 0.315 & 132.8 & 0.0069 \\ \text { KL-11 } & 0.165 & 518.7 & 0.0009 \\ \text { KL-28 } & 0.349 & 111.2 & 0.0091 \\ \text { GB-49 } & 0.092 & 34.19 & 0.0078\end{array}$

$\begin{array}{lll}0.70681 \pm 1 & 0.70674 \pm 1 & -244 \\ 0.70682 \pm 1 & 0.70676 \pm 1 & -241 \\ 0.70663 \pm 4 & 0.70662 \pm 4 & -256 \\ 0.70648 \pm 1 & 0.70646 \pm 1 & -271 \\ 0.70597 \pm 1 & 0.70592 \pm 1 & -326 \\ 0.70650 \pm 1 & 0.70642 \pm 1 & -275 \\ 0.70576 \pm 1 & 0.70575 \pm 1 & -342 \\ 0.70581 \pm 1 & 0.70570 \pm 1 & -347 \\ 0.70608 \pm 1 & 0.70599 \pm 1 & -319\end{array}$

$\begin{array}{ll}5.7 & -6.8 \\ 6.0 & -7.4 \\ 5.0 & -7.5 \\ 3.1 & -6.9 \\ 6.4 & -6.9 \\ 4.5 & -7.9 \\ 5.8 & -6.3 \\ 4.5 & -7.2 \\ 4.9 & -2.2\end{array}$

$\begin{array}{lll}0.149 & 1445 & 0.0102 \\ 1.10 & 623 & 0.0601 \\ 0.248 & 2371 & 0.0073 \\ 0.325 & 1755 & 0.0194 \\ 0.447 & 1696 & 0.0320 \\ 0.940 & 2531 & 0.0479 \\ 0.122 & 674 & 0.0112 \\ 1.06 & 3223 & 0.0077 \\ 5.48 & 5781 & 0.5110\end{array}$

II. Minto Inlet Formation

$\begin{array}{llll}\text { GB-10 } & 0.060 & 220.9 & 0.0008\end{array}$

$\begin{array}{llll}\text { GB-10 } & 0.060 & 220.9 & 0.0008\end{array}$

\section{$0.70562 \pm 1$} $0.70588 \pm 1$

$\begin{array}{ll}0.70561 \pm 1 & -356 \\ 0.70581 \pm 1 & -336\end{array}$

\section{1}

-7.4
-4.5

0.667

1414

0.1030

III. Reynolds Point Formation

$\begin{array}{llll}\text { WI-76 } & 0.622 & 273.0 & 0.0066 \\ \text { WI-66 } & 0.208 & 241.3 & 0.0025 \\ \text { WI-55 } & 0.170 & 398.3 & 0.0012 \\ \text { WI-54 } & 0.166 & 170.2 & 0.0028 \\ \text { WI-51 } & 0.315 & 187.9 & 0.0048 \\ \text { WI-49 } & 0.075 & 32.09 & 0.0067\end{array}$

$0.70578 \pm 1$
$0.70634 \pm 1$
$0.70591 \pm 2$
$0.70657 \pm 1$
$0.70789 \pm 1$
$0.70884 \pm 1$

$0.70570 \pm 1$

$0.70631 \pm 1$

$0.70590+2$

$-328$

$0.70654 \pm 1 \quad-264$

$0.70783 \pm 1 \quad-134$

$0.70876 \pm 1$

-347
-286
-328
-264
-134
-42

4.7
3.8
4.2
3.3
2.9
4.9

-7.2
-8.0
-7.7
-9.3
-11.0
-6.9

0.465
0.772
0.643
1.65
0.830
9.30

* All concentrations (ppm) are calculated for the dissolved fraction.

** ${ }^{87} \mathrm{Sr} / 86 \mathrm{Sr}$ measured using ${ }^{86} \mathrm{Sr} / 88 \mathrm{Sr}=0.1194$ to correct for fractionation in the mass spectrometer.

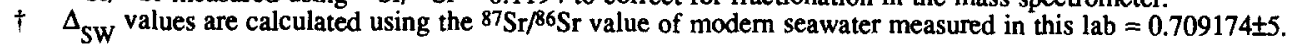

$+\dagger \delta^{13} \mathrm{C}$ and $\delta^{18} \mathrm{O}$ are given relative to the PDB standard and have typical uncertainties of \pm 0.1 and \pm 0.2 respectively. 

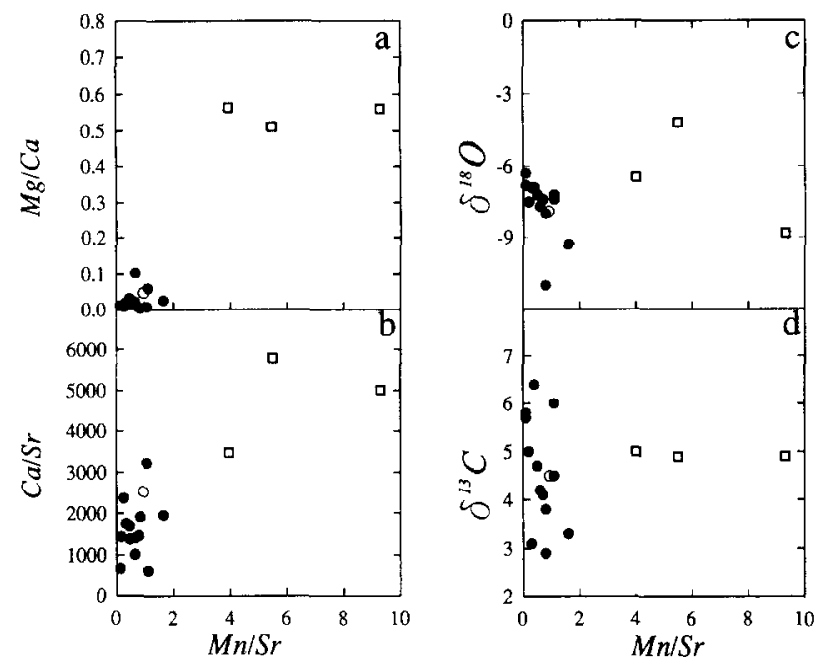

FIG. 2, Elemental and stable isotope ratios plotted vs. $\mathrm{Mn} / \mathrm{Sr}$ ratio (used as index of alteration). The three dolomites (open squares; high $\mathrm{Mg} / \mathrm{Ca}$ ratios) show high $\mathrm{Mn} / \mathrm{Sr}$ and $\mathrm{Ca} / \mathrm{Sr}$ ratios and a wide range in $\delta^{18} \mathrm{O}$ values. $\delta^{13} \mathrm{C}$ values show a large range but do not correlate with $\mathrm{Mn} / \mathrm{Sr}$ ratios. Limestones are shown with solid and open circles. Samples that are considered altered are shown in open symbols (see text).

The $\delta^{18} \mathrm{O}$ value of carbonate rocks is another sensitive indicator of alteration (BRAND and VEIZER, 1981). Most of our limestone samples show a limited range in $\delta^{18} \mathrm{O}$ values from -6 to -8 , which may reflect primary values. Two limestones have noticeably lower values, while the high $\delta^{18} \mathrm{O}$ values were obtained on dolomites (Fig. 2c). The low $\delta^{18} \mathrm{O}$ values are most likely the result of alteration by meteoric water. The fact that some of the altered samples have high $\delta^{18} \mathrm{O}$ values (Fig. 2c) may indicate that not all alteration resulted from interaction with meteoric water. Some material, for example, may have been leached from a clastic component in the carbonate matrix. The $\delta^{13} \mathrm{C}$ values of the limestones are quite variable $(+3$ to +6.5$)$ regardless of the $\mathrm{Mn} / \mathrm{Sr}$ ratio (Fig. $2 \mathrm{~d}$ ). This is not surprising given the strong secular variation in $\delta^{13} \mathrm{C}$ previously demonstrated for Neoproterozoic carbonates (KNOLL et al., 1986).

The variations of $\delta^{18} \mathrm{O}, \delta^{13} \mathrm{C}$, and ${ }^{87} \mathrm{Sr} /{ }^{86} \mathrm{Sr}$ as a function of age in the Shaler Group are shown in Fig. 3. The limestones show very smooth and systematic variation with time for all three isotope systems. The dolomites plot distinctly off the main trends. Based on the elemental and isotopic systematics, we feel confident that the isotopic compositions of the dolomites (\#GB-49, GB-3, and WI-49, shown as open squares in Figs. 2 and 3) do not reflect primary isotopic values. In addition, the limestone sample \#KL-50 (open circle), with a high ${ }^{87} \mathrm{Sr} /{ }^{86} \mathrm{Sr}$ value (relative to samples of similar age) is also likely altered as it plots distinctly off the limestone trend for all isotope systems. Sample \#WI-51 has a low $\mathrm{Mn} / \mathrm{Sr}$ ratio; however, it has also a fairly low $\delta^{18} \mathrm{O}$ value of -11 . We tentatively include the sample in the curve. Overall, the fact that all the samples that we have rejected based on elemental and stable isotope criterions have higher ${ }^{87} \mathrm{Sr} /{ }^{86} \mathrm{Sr}$ ratios than neighboring samples (Fig. 3) gives us confidence that the criteria we have adopted for sample acceptance are fairly robust.

\section{DISCUSSION}

\section{Comparison with ${ }^{87} \mathrm{Sr} /{ }^{86} \mathrm{Sr}$ of other Neoproterozoic Carbonate Sequences}

The data presented in this study provide a stratigraphically coherent view of the $\mathrm{Sr}$ isotope variation in seawater during the time interval represented by the Shaler strata. The only comparable study of Proterozoic seawater $\mathrm{Sr}$ isotope composition from a single basin is that of DERRY et al. (1989) of the Neoproterozoic (ca. 700-800 Ma) Akademikerbreen Group, Spitsbergen. Although DERRY et al. (1989) were only able to draw a band that covered the scatter in their data, there is enough resolution in their curve to attempt correlation between the Shaler and Akademikerbreen groups. The two data sets and their respective schematic stratigraphic columns are shown in Fig. 4. The curve we drew through the data of DERRY et al. (1989) is not meant to reflect detail in the $\mathrm{Sr}$ isotopic composition of seawater for that time period. However, we think the general trend in the Akademikerbreen data, starting at a ${ }^{87} \mathrm{Sr} /{ }^{86} \mathrm{Sr}$ ratio of 0.7067 in the lower part of the section, briefly decreasing and then rising to a high value of 0.7074 and then gradually decreasing back to 0.7068 in the upper part of the section (Fig. 4), reflects true seawater values. We interpret the stratigraphic relationships of the two basins as shown in Fig. 4; the lowermost Akademikerbreen group is time equivalent to the upper Wynniatt formation of the Shaler Group. As the Akademikerbreen $\mathrm{Sr}$ isotope curve

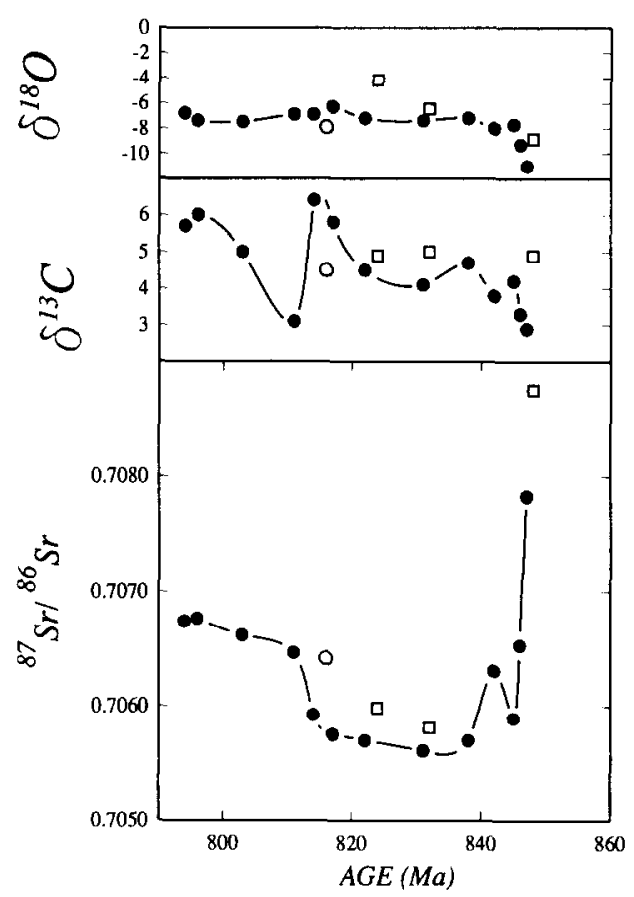

FIG. 3. $\delta^{18} \mathrm{O}(\mathrm{a}), \delta^{13} \mathrm{C}(\mathrm{b})$, and ${ }^{87} \mathrm{Sr} /{ }^{86} \mathrm{Sr}$ (c) variations in Shaler Group limestones and dolomites for the period 790-850 Ma. The data excluded from the curve, shown in open symbols, correspond to the same samples shown as open symbols in Fig. 2 and are assumed to be altered. The smooth and systematic variation in ${ }^{87} \mathrm{Sr} /{ }^{86} \mathrm{Sr}$ values reinforce the idea that the curve represents seawater composition for the period 790-850 Ma. One limestone sample (KL-50, open circle) plots off the main isotopic trends and is considered to be altered. It has somewhat high $\mathrm{Ca} / \mathrm{Sr}$ and $\mathrm{Mg} / \mathrm{Ca}$ ratios. 


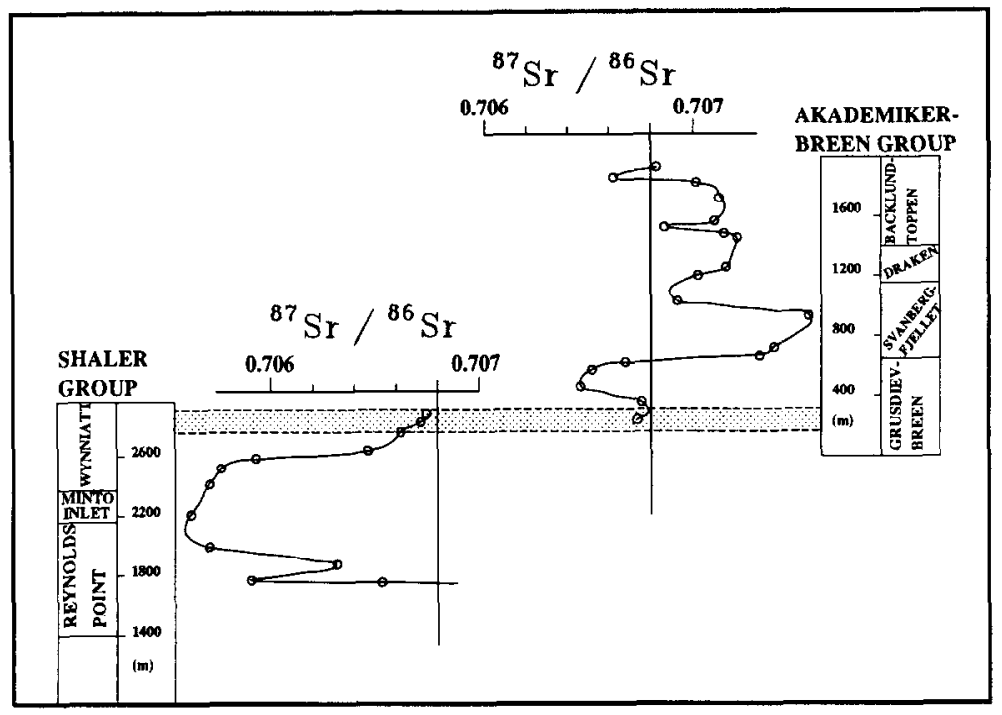

FIG. 4. Stratigraphic correlation between the Shaler Group, Victoria Island, and Akademikerbreen Group, Spitsbergen, based on initial ${ }^{87} \mathrm{Sr} /{ }^{86} \mathrm{Sr}$ ratios. The stratigraphic correlation is consistent with radiometric ages, paleontological and carbon isotope data. Data for the Akademikerbreen Group is from DERRY et al. (1989).

contains no other values that are as low as those recorded in the Shaler Group, there can be no more extensive overlap. While we cannot eliminate the possibility of a small gap between the two sections, microfossils (BUTTERFIELD and RAINBIRD, 1988) and carbon isotope profiles (HAYES et al., unpub. data; also compare Table 2 with $\delta^{13} \mathrm{C}$ values of the lower Akademikerbreen in KNOLL et al., 1986) support the correlation shown here and indicate that any time gap between the upper Shaler and lower Akademikerbreen cannot be large.

We combined our data with those of DERRY et al. (1989) and VEIZER et al. (1983) in order to construct the general seawater curve for the Neoproterozoic shown in Fig. 5. Individual sample positions used to draw the curve are indicated on the figure except for the 500-540 Ma period where we used the curves of BURKE et al. (1982) and KETO and JACOBSEN (1987). As discussed above, we believe that there is a slight overlap or at least continuity between the Shaler and Akademikerbreen sections. However, we have not accounted for possible stratigraphic (time) breaks within each section. In addition, relative age distributions within a given section are assigned using an empirical basin subsidence model; the age distribution is likely to be less uniform than shown in Fig. 5 ,

\section{Modeling of Sr and Nd Seawater Cycles}

The ${ }^{87} \mathrm{Sr} /{ }^{86} \mathrm{Sr}$ value of seawater primarily reflects the balance between the river water ( $R W$ ) flux of Sr from the continents and the hydrothermal water (HW) flux of Sr from mid-ocean ridge basalts (SPOONER, 1976; ALBARÈDE et al., 1981; VEIZER, 1985; GOLDSTEIN and JACOBSEN, 1987; ALBARÈDE and MICHARD, 1987). It may also vary as a result of changes in the $\mathrm{Sr}$ isotopic composition of the continental input.

It has been suggested that differences in $\epsilon_{\mathrm{Nd}}$ of the oceans might be caused by differences in the amount of hydrothermal circulation between oceans or, by inference, to differing contributions from mid-ocean ridge basalts. However, GoLDSTEIN and JACOBSEN ( 1987) demonstrated that even the upper limit of the present hydrothermal flux of Nd is very small (on the order of $\leq 2 \%$ ) compared to the flux of $\mathrm{Nd}$ from the continents. On the other hand, the $\mathrm{Sr}$ isotopic ratio of the oceans today requires a contribution to ocean water $\mathrm{Sr}$ from hydrothermal water $\mathrm{Sr}$ of $\sim 13 \%$ of the river water flux of $\mathrm{Sr}$. For both $\mathrm{Sr}$ and $\mathrm{Nd}$, the river water flux and isotopic ratios appear to be the dominant controls on seawater isotopic values. Thus, modern hydrothermal water inputs significantly affect seawater $\mathrm{Sr}$ isotopic values but are not important for seawater $\mathrm{Nd}$ isotopic values.

Calculations based on the present $\mathrm{Nd}$ and $\mathrm{Sr}$ budgets and $\mathrm{Nd}$ and $\mathrm{Sr}$ isotopic variations in ancient seawater can be used to estimate changes in the relative importance of the river flux $\left(J^{\mathrm{RW}}\right)$ and the hydrothermal flux $\left(J^{\mathrm{HW}}\right)$ of $\mathrm{Sr}$ and $\mathrm{Nd}$ to the oceans through time. The mass balance equations for the $\epsilon_{\mathrm{Sr}}$ and $\epsilon_{\mathrm{Nd}}$ values of seawater (SW) as functions of time are, to a first approximation (cf. GOLDSTEIN and JACOBSEN 1987; JACOBSEN and PIMENTEL-KLOSE, 1988a,b; DERRY and JACOBSEN, 1988),

$$
\begin{aligned}
\tau_{\mathrm{Sr}}\left[\frac{d \epsilon_{\mathrm{Sr}}^{\mathrm{SW}}}{d t}\right] & =p_{\mathrm{Sr}}\left(\epsilon_{\mathrm{Sr}}^{\mathrm{HW}}-\epsilon_{\mathrm{Sr}}^{\mathrm{SW}}\right)+\left[\epsilon_{\mathrm{Sr}}^{\mathrm{RW}}-\epsilon_{\mathrm{Sr}}^{\mathrm{SW}}\right] \\
0 & =p_{\mathrm{Nd}}\left(\epsilon_{\mathrm{Nd}}^{\mathrm{HW}}-\epsilon_{\mathrm{Nd}}^{\mathrm{SW}}\right)+\left[\epsilon_{\mathrm{Nd}}^{\mathrm{RW}}-\epsilon_{\mathrm{Nd}}^{\mathrm{SW}}\right]
\end{aligned}
$$

where $p_{\mathrm{Sr}} \equiv J_{\mathrm{Sr}}^{\mathrm{HW}} / J_{\mathrm{Sr}}^{\mathrm{RW}}$ and $p_{\mathrm{Nd}} \equiv J_{\mathrm{Nd}}^{\mathrm{HW}} / J_{\mathrm{Nd}}^{\mathrm{RW}}$ are the hydrothermal to river water flux ratios for $\mathrm{Sr}$ and $\mathrm{Nd}$, respectively. The residence time of $\mathrm{Sr}\left(\tau_{\mathrm{Sr}}\right)$ in the oceans is much longer than the interocean mixing time whereas the residence time of $\mathrm{Nd}$ is of the same order of magnitude as the interocean mixing time. Thus, the residence time of $\mathrm{Nd}$ in the ocean is so short that the left-hand side of the Nd of Eqn. (7) is essentially zero.

All input values for Eq. (6) are well constrained through time except for $\epsilon$ S $\mathrm{RT}$ and $p_{\mathrm{S} r}$. To solve for these two variables 


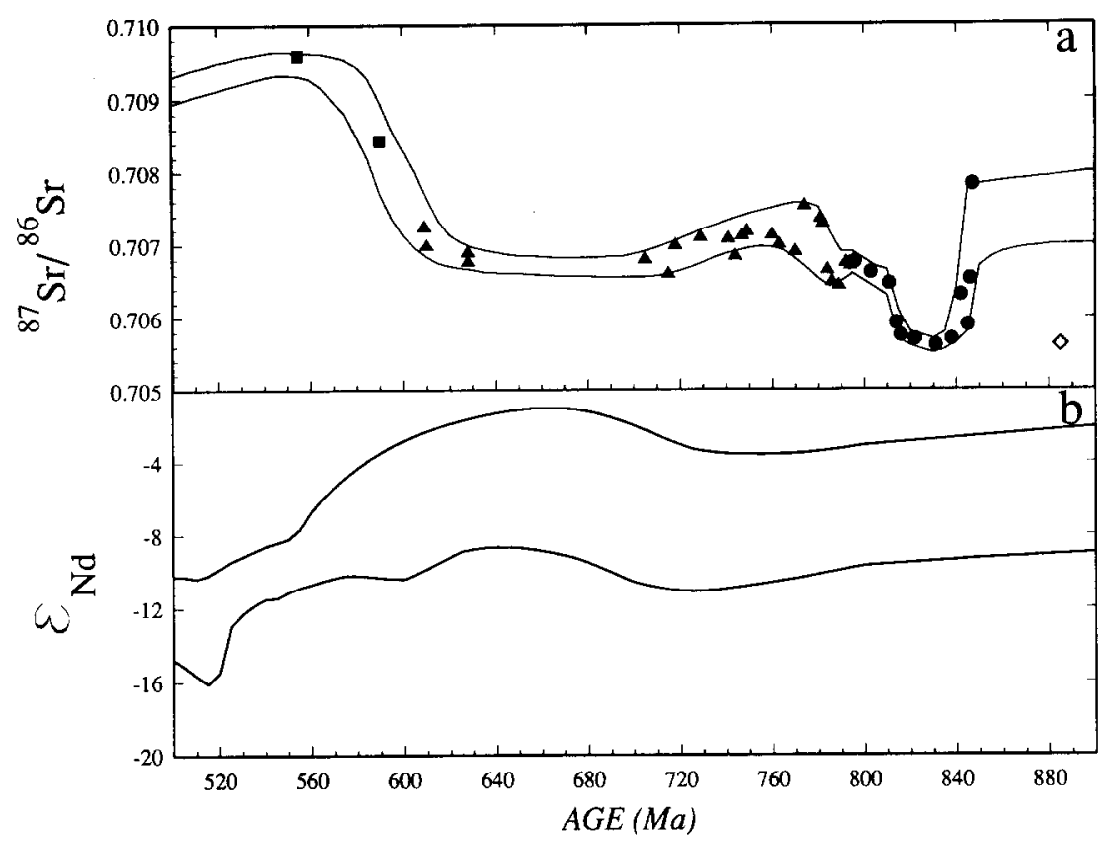

FIG. 5. (a) Composite ${ }^{87} \mathrm{Sr} /{ }^{86} \mathrm{Sr}$ seawater curve for the period 500-900 Ma. Solid circles are from this study, triangles from DERRY et al. (1989), and solid squares (Nama) and open diamond symbol (Adrar) from VEIzER et al. (1983). Data for the period 500-540 Ma is from BURKE et al. (1982) and KETO and JACOBSEN (1987). The band covers the estimated probable limits on ${ }^{87} \mathrm{Sr} /{ }^{86} \mathrm{Sr}$ in seawater for this period. (b) Estimated ranges in $\epsilon_{\mathrm{Nd}}$ values for average seawater for the period 500-900 Ma after KETO and JACOBSEN (1988) and JACOBSEN and PIMENTEL-KLOSE (1988b).

in the Sr seawater cycle through time, at least one other independent expression is needed. The relationship between $\mathrm{Nd}$ and $\mathrm{Sr}$ inputs in river waters through time can be used to constrain $\epsilon_{\mathrm{Sr}}^{\mathrm{RW}}$ and $p_{\mathrm{Sr}}$ both as functions of time. GoLDSTEIN and JACOBSEN ( 1987) showed that $\epsilon_{\mathrm{Nd}}$ and $\epsilon_{\mathrm{Sr}}$ in present river waters roughly obey the following relationship:

$$
\epsilon \underset{\mathrm{S} r}{\mathrm{RW}} \approx \alpha \epsilon \underset{\mathrm{Nd}}{\mathrm{RW}}+\beta
$$

where $\alpha$ and $\beta$ are constants that may be obtained from a river water $\epsilon_{\mathrm{Sr}}-\epsilon_{\mathrm{Nd}}$ plot, since, through the Phanerozoic, $p_{\mathrm{Nd}}$ $\approx 0$, the $\epsilon_{\mathrm{Nd}}$ equation reduces to: $\epsilon \mathrm{Sd} \approx \epsilon_{\mathrm{Nd}}^{\mathrm{RW}}$. However, for the Archean and perhaps part of the Proterozoic, $p_{\mathrm{Nd}}$ may be very high, so this simplification is not necessarily valid across all of Earth history.

We can calculate the flux ratio $p_{\mathrm{Sr}}$ as function of time once the $\epsilon_{\mathrm{Nd}}$ and $\epsilon_{\mathrm{Sr}}$ curves of seawater are known. It follows from Eqns. (6), (7), and (8) that

$$
p_{\mathrm{S} \mathrm{r}}=\frac{\tau_{\mathrm{Sr}}\left[\frac{d \epsilon_{\mathrm{Sr}}^{\mathrm{SW}}}{d t}\right]-\left[\alpha \epsilon_{\mathrm{Nd}}^{\mathrm{SW}}+\beta-\epsilon_{\mathrm{Sr}}^{\mathrm{SW}}\right]}{\left[\epsilon_{\mathrm{Sr}}^{\mathrm{HW}}-\epsilon_{\mathrm{Sr}}^{\mathrm{SW}}\right]-\alpha \gamma\left[\epsilon_{\mathrm{Nd}}^{\mathrm{HW}}-\epsilon_{\mathrm{Nd}}^{\mathrm{SW}}\right]}
$$

where $\gamma=p_{\mathrm{Nd}} / p_{\mathrm{Sr}}=(\mathrm{Nd} / \mathrm{Sr})_{\mathrm{HW}} /(\mathrm{Nd} / \mathrm{Sr})_{\mathrm{Rw}}$ and thus $p_{\mathrm{Nd}}$ $=\gamma p_{\mathrm{Sr}}$.

To calculate $p_{\mathrm{Sr}}$ as a function of time from equation (9) we need

1) The seawater isotopic curves for $\mathrm{Sr}$ and $\mathrm{Nd}$. The $\epsilon_{\mathrm{Sr}}^{\mathrm{SW}}$-time curve we used was calculated from the ${ }^{87} \mathrm{Sr} /{ }^{86} \mathrm{Sr}$ curve in Fig. 5a using Eq. (5) while the $\epsilon_{\mathrm{Nd}}^{\mathrm{SW}}$-time curve used is shown in Fig. 5b. It is the curve reported by KETO and JACOBSEN (1988) and JACOBSEN and PIMENTELKLOSE (1988b).
2) The hydrothermal water $\epsilon_{\mathrm{Sr}}$ and $\epsilon_{\mathrm{Nd}}$ curves. The $\epsilon_{\mathrm{Nd}}^{\mathrm{HW}}$ value through time was approximated by the depleted mantle curve with a present day $\epsilon_{\mathrm{Nd}}^{\mathrm{HW}}$ value of +10 . This value was assumed to decrease linearly to 0 at $4.5 \mathrm{Ga}$ ago. Similarly, $\epsilon_{\mathrm{Sr}}^{\mathrm{HW}}$ value through time was obtained using a present-day $\epsilon_{\mathrm{Sr}}^{\mathrm{HW}}$ value of -13.3 (cf. GOLDSTEIN and JACOBSEN, 1987) and increasing to 0 at $4.5 \mathrm{Ga}$ ago.

3 ) Estimates of $\alpha, \beta, \gamma$, and $\tau_{\mathrm{Sr}}$ were obtained from the work of GOLDSTEIN and JACOBSEN (1987). The values used are $\alpha=-6.44, \beta=36$ (slightly modified to take into account unpublished results ), $\gamma=0.09$ and $\tau_{\mathrm{Sr}}=4.1 \mathrm{Ma}$.

The values and curves given were used to evaluate Eqn. (9), and the resulting curve for $p_{\mathrm{Sr}}^{-1}$ is given in Fig. 6. We show $p_{\mathrm{Sr}}^{-1}$ in this figure so that high continental inputs correspond to high values while high hydrothermal inputs correspond to low values. This curve was also normalized to the present hydrothermal to river flux ratio $\left(p_{\mathrm{Sr}}(0)=0.13\right.$; GOLDSTEIN and JACOBSEN, 1987). The width of the band shown for the $p_{\mathrm{Sr}}^{-1}$ curve reflects the uncertainty in estimating this ratio from the $\epsilon_{\mathrm{Sr}}$ and $\epsilon_{\mathrm{Nd}}$ curves shown in Fig. 5.

\section{Variations in Erosional and Hydrothermal Fluxes during the Neoproterozoic}

An earlier evaluation of $p_{\mathrm{Sr}}$ for the past $0.75 \mathrm{Ga}$ shows peaks in the river to hydrothermal flux curve for $\operatorname{Sr}\left(p_{\mathrm{Sr}}^{-1}\right)$ at 0 , 0.4, and $\sim 0.6 \mathrm{Ga}$ ago (JACOBSEN, 1988; see inset in Fig. 6). The peaks were interpreted as times of very high continental erosion rates. During the Archean, both $p_{\mathrm{Sr}}$ and $p_{\text {Nd }}$ show a strong increase indicating a regime dominated by hydrothermal circulation (JACOBSEN and PIMENTEL-KLOSE, $1988 \mathrm{a}, \mathrm{b})$. 


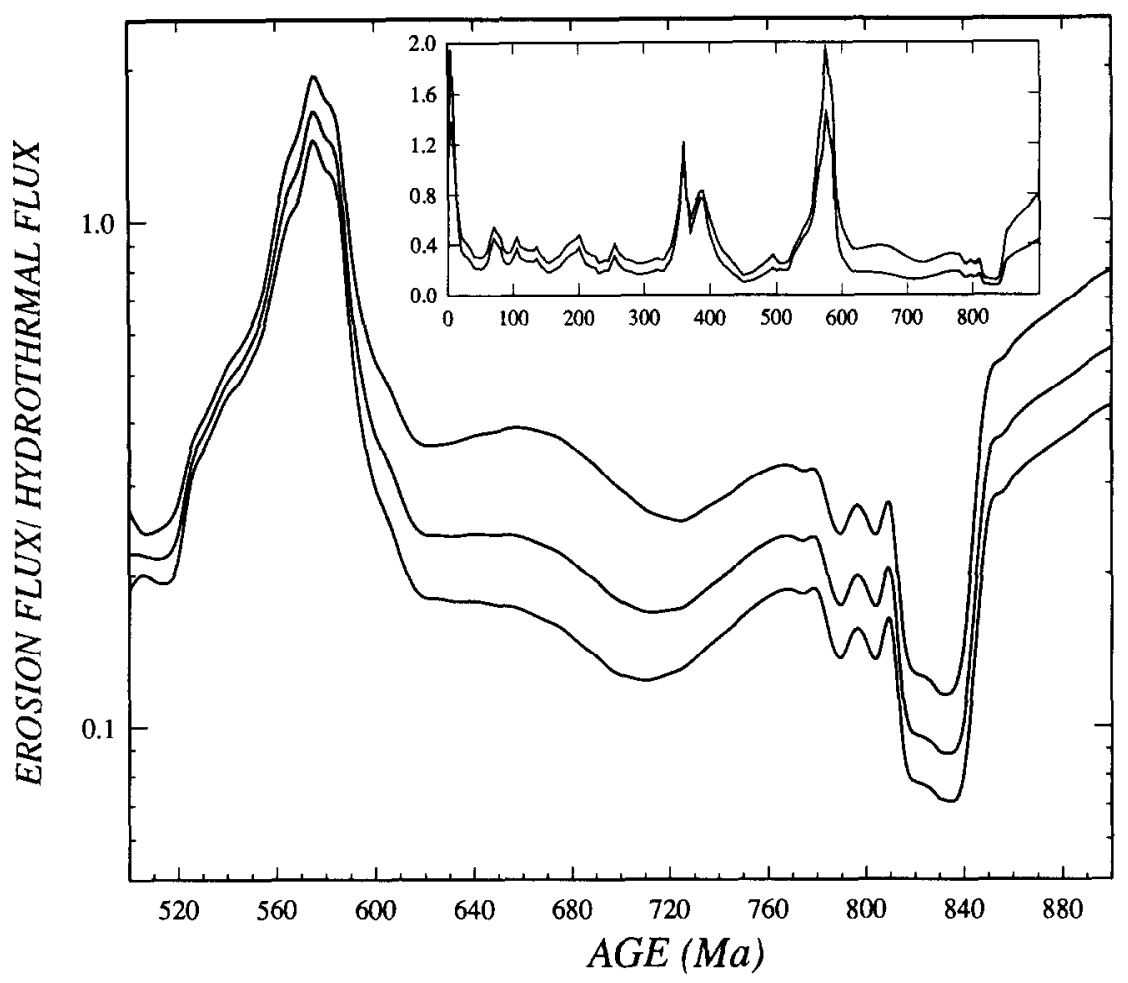

FIG. 6. River to hydrothermal water $\mathrm{Sr}$ flux $\left(p_{\mathrm{Sr}_{\mathrm{r}}}{ }^{1}\right)$ curve vs. time for the Neoproterozoic. The curve is normalized to the present-day river to hydrothermal water flux ratio for Sr. See text for discussion on the derivation of the model. The large low at ca. $830 \mathrm{Ma}$. is correlated with a large input of juvenile crust and ocean rifting associated with the PanAfrican and related events, while the large peak at ca. $570 \mathrm{Ma}$ is correlated with high erosion rates due to continental collision at this time. The inset shows a Sr flux curve for the period 0-900 Ma with the 0-500 Ma portion from JACOBSEN (1988) and the 500-900 Ma portion is from this work.

The ambient river to hydrothermal water $\mathrm{Sr}$ flux curve $\left(p_{\mathrm{Sr}}^{-1}\right)$ for much of the Neoproterozoic is $0.25 \pm 0.15$ relative to the present value of this ratio (Fig. 6). The prominent peak at ca. $570 \mathrm{Ma}$, suggesting a 1.5 times present rate of erosion, coincides with a peak in global erosion rate at $\sim 600$ Ma discussed by JACOBSEN ( 1988). The age difference in the position of the peaks is due to repositioning of the CambrianPrecambrian boundary at $540 \mathrm{Ma}$ in our $\epsilon_{\mathrm{Sr}}^{\mathrm{SW}}$-time input curve (Fig. 5a). The low ambient erosion rate indicated for the rest of the curve reflects the moderately low but uniform $\mathrm{Sr}$ isotope composition of seawater for that part of the Neoproterozoic. The river to hydrothermal flux curve $\left(p_{\mathrm{Sr}}^{-1}\right)$ dips to a profoundly low value of about 0.10 relative to the present at ca. $830 \mathrm{Ma}$. This corresponds to a hydrothermal flux contribution for $\mathrm{Sr}$ to the oceans of about ten times the presentday value and 2-3 times the ambient Neoproterozoic value. A present-day hydrothermal flux higher than the value of GOLDSTEIN and JACOBSEN (1987) by a factor of 3 has been suggested by PALMER and EDMOND (1989). Regardless of the present-day value the period between $810-840 \mathrm{Ma}$ appears to represent a time of extremely high hydrothermal flux. The curve changes rapidly to higher values during $840-900 \mathrm{Ma}$, although with large uncertainties. This is supported by some data (VEIZER et al., 1983) that suggest generally high ${ }^{87} \mathrm{Sr} /$ ${ }^{86} \mathrm{Sr}$ values prior to the extremely $l o w{ }^{87} \mathrm{Sr} /{ }^{86} \mathrm{Sr}$ values shown by our data, possibly corresponding to the Grenville orogeny and associated events at ca. $1000 \mathrm{Ma}$.
The lack of detailed information on the configuration of the continental crust makes it difficult to attribute anomalies in the flux-time curve to specific geologic events. However, we are able to narrow the choices using available geologic data. Principal tectonic events of the Neoproterozoic include Pan-African orogenesis and related rifting events (KRÖNER, 1979; GASS, 1981; CAHEN et al., 1984; PALLISTER et al., 1987; PORADA, 1989; BERHE, 1990). Variation in the $\mathrm{Sr}$ flux ratiotime curve in Fig. 6 closely coincide with the large-scale events in the Pan-African orogen. The initiation of rift basins floored by oceanic crust is indicated by the cluster of the oldest PanAfrican ophiolite ages at around $830 \mathrm{Ma}$ (PALLISTER et al., 1987). In addition, this early period of the Pan African is characterized by the production of large amounts of juvenile crust (ClaESSON et al., 1984; HARRIS et al., 1984; KRONER et al., 1987; CABY et al., 1989). The combined effect of largescale production of depleted mantle-like crust and widespread oceanic rifting may explain the large peak seen in the hydrothermal flux between $810-840 \mathrm{Ma}$ (Fig. 6). It has been suggested that banded iron formations (BIFs) were formed during periods of high hydrothermal flux (JACOBSEN and PIMENTEL-KLOSE, 1988a,b). The last of the large BIF deposits were formed during the Neoproterozoic after a hiatus during the Middle Proterozoic (James, 1983). Along with the Sr isotopic signature, these late stage iron formations and anomalous $\delta^{13} \mathrm{C}$ signals indicate unusual oceanic conditions during much of the later Neoproterozoic Era (DERRY et al., 
1990; KNOLL et al., 1986; KNOL.I and WAI.KER, 1990; KAUFMAN et al., 1991).

The alternative possibility for explaining the high hydrothermal contribution to $\mathrm{Sr}$ in the oceans at $810-840 \mathrm{Ma}$ is a drastic reduction in the riverine input into the ocean(s). However, there is no record of major reconfiguration of continents around 800-850 Ma (PIPER, 1982; MCWILliaMs, 1981 ) that would lead to a severe reduction in riverine input.

There is wide spread evidence for a major episode of continent-continent collision at the end of the Proterozoic in the Pan-African belt (SHACKLETON, 1986; KRONER et al., 1987; CABY et al., 1989; PORADA, 1989). In addition, late stage Pan-African igneous activity is characterized by within-plate, recycled crustal material (RIES et al., 1985; CABY et al., 1989). The high erosion rate inferred by the prominent peak at the end of the Proterozoic (Fig. 6a) is consistent with the above observations. It has been suggested that the steep rise in the Cenozoic ${ }^{87} \mathrm{Sr} /{ }^{86} \mathrm{Sr}$ seawater curve can be accounted for by the high rates of uplift during the Cenozoic (REYMO et al., 1988 ).

\section{CONCLUSIONS}

The secular variation of seawater ${ }^{87} \mathrm{Sr} /{ }^{86} \mathrm{Sr}$ is a valuable tool in understanding geological processes through time. The abundant carbonates found in many Proterozoic basins provide an opportunity to extend the record of secular variation in seawater ${ }^{87} \mathrm{Sr} /{ }^{86} \mathrm{Sr}$ to this time period.

1) While difficulties exist in establishing the seawater $\mathrm{Sr}$ isotope curve due to diagenetic alteration and stratigraphic resolution, it is possible to overcome these difficulties by careful screening of samples using petrography, elemental, and isotopic data such as $\mathrm{Mn} / \mathrm{Sr}$ and $\mathrm{Rb} / \mathrm{Sr}$ ratios, $\delta^{18} \mathrm{O}$, and $\delta^{13} \mathrm{C}$. We have becn able to achicve a reasonable dcgree of stratigraphic resolution by analyzing samples collected from measured sections in a single basin. We believe we have demonstrated that in the Shaler Group many limestones contain near-primary ${ }^{87} \mathrm{Sr} /{ }^{86} \mathrm{Sr}$ and that the Neoproterozoic curve may, with more work, be as precisely defined as the Phanerozoic curve (except for uncertainties in absolute ages).

2) The upper part of the Shaler Group is correlated, based on ${ }^{87} \mathrm{Sr} /{ }^{86} \mathrm{Sr}$ data, with the lower part of the Akademikerbreen Group, Spitsbergen. The correlation is consistent with the available age data on the basins. Strontium isotope data should have great utility in correlating widely separated basins as similar high-quality data become available.

3) The Neoproterozoic ${ }^{87} \mathrm{Sr} /{ }^{86} \mathrm{Sr}$ curvc is striking in terms of both the extremely low values found in samples at ca. $830 \mathrm{Ma}(0.7056)$ and the rapid shift to unusually high ratios $(0.709)$ during the latest Proterozoic. Typical Neoproterozoic ${ }^{87} \mathrm{Sr} /{ }^{86} \mathrm{Sr}$ ratios are about 0.707 .

4) In modeling the Neoproterozoic Sr and Nd isotopic composition of seawater, we found that the period 840-810 Ma represents a time of very high hydrothermal to river water flux ratio for $\mathrm{Sr}$ which is most likely due to an unusually high hydrothermal flux through ocean crust. A very low flux ratio suggesting unusually high erosion rates, up to 1.5 times present-day rates (which themselves are unusually high relative to the Phanerozoic mean) are inferred for the latest Proterozoic, at ca. 570 Ma.
5) Tectonic events associated with Neoproterozoic continental breakup and the Pan-African orogeny correlate well with the flux curve as well as the ${ }^{87} \mathrm{Sr} /{ }^{86} \mathrm{Sr}$ curve and likely provide at least a partial explanation for its shape. The period of apparently high hydrothermal flux between 810 $840 \mathrm{Ma}$ coincides with production of large amounts of juvenile crust and rifting of a supercontinent. In contrast, the end of the Proterozoic appears to be characterized by high erosion rates, with a peak at ca. $570 \mathrm{Ma}$. The high erosion rate may be reflecting the continent-continent collision event at the end of the Proterozoic and change of sources of igneous activity in the Pan-African belt from primitive to evolved continental sources.

As high quality data become available for more of the Proterozoic, we may be able to utilize the $\mathrm{Sr}$ isotopic composition of marine carbonates to detect large-scale crustal processes through a large span of Earth history. Such knowledge will be useful in evaluating the evolution of plate tectonics through time.

Acknowledgments-The isotope work was supported by NSF grant EAR-8904593 to SBJ; field work was supported in part by NASA grant NAGW-893 and DOE grant DE-FG-88ER13978 (to AHK) the National Geographic society, and the Shaler Fund of Harvard University. We thank A. J. Kaufman and J. Nevins for their assistance in obtaining the stable isotope data. We have benefited from constructive reviews by W. T. Holser, Z. E. Peterman, and A. M. Stueber.

Editorial handling: G. Faure

\section{REFERENCES}

AITKEN J. D. (1981) Stratigraphy and scdimentology of the Upper Proterozoic Little Dal Group, Northwest Territories. Geol. Surv. Canada Paper 81-10, pp. 47-71.

ALBAREDE F. and MICHARD A. ( 1987) Evidence for slowly changing ${ }^{87} \mathrm{Sr} /{ }^{86} \mathrm{Sr}$ in runoff from freshwater limestones of southern France. Chem. Geol. 64, 55-65.

Albarede F., Michard A., Minster J. F., and Michard G. ( 1981 ) ${ }^{87} \mathrm{Sr} /{ }^{86} \mathrm{Sr}$ ratios in hydrothermal waters and deposits from the East Pacific Rise at $21^{\circ}$ N. Earth Planet Sci. Lett. 55, 229-236.

ARMSTrong R. L., EISENBACHER G. H., and EVANS P. D. (1982) Age and stratigraphic-tectonic significance of Proterozoic diabase sheets, Mackenzie Mountains, northwestern Canada. Canadian J. Earth Sci. 19, 317-323.

BERHE S. M. (1990) Ophiolites in northeast and east Africa: Implications for Proterozoic crustal growth. I. Geol. Soc. London 147, 41-57.

BRAND U. and VEIzER J. ( 1980) Chemical diagenesis of multicomponent carbonate system-1: Trace elements. J. Sediment. Petrol. 50, $1219-1236$.

BRAND U. and VEIZER J. ( 1981 ) Chemical diagenesis of multicomponent carbonate systcm-2: Stable Isotopes. J. Sediment. Petrol. 51, 987-998.

Burke W. M., Denison R. E., Hetherington E. A., Koepnick R. B., NeLSON M. F., and OMO J. B. (1982) Variations of seawater ${ }^{87} \mathrm{Sr} /{ }^{86} \mathrm{Sr}$ throughout Phanerozoic time. Geology 10, 516-519.

BuTtERFIELD N. J. and RAINBIRD R. H. (1988) The paleobiology of two Proterozoic shales. Geol. Soc. Amer. Prog. 20, A 103.

Caby R., Andreopoulos-Renaud U., and PIN C. (1989) Late Proterozoic arc-continent and continent-continent collision in the Pan-African trans-Saharan belt of Mali. Canadian J. Earth Sci. 26, $1136-1146$.

Cahen L., Snelling N. J., Delhal J., and Vall J. R. (1984) The Geochronology and Evolution of Africa. Clarendon Press.

Claesson S., Pallister J. S., and Tatsumoto M. (1984) Samarium-Neodymium data on two Late Proterozoic ophiolites of Saudi Arabia and implications for crustal and mantle evolution. Contrib. Mineral. Petrol. 85, 244-252. 
DePaolo D. J. (1986) Detailed record of the Neogene Sr isotopic evolution of seawater from DSDP Site 590B. Geology 14, 103106.

DEPAOLO D. J. and INGRAM B. L. ( 1985) High resolution stratigraphy with strontium isotopes. Science 227, 938-941.

DEPAOLO D. J. and WASSERBURG G. J. (1977) The sources of island arcs as indicated by $\mathrm{Nd}$ and $\mathrm{Sr}$ isotopic studies. Geophys. Res. Lett. 4, 465-468.

DERRY L. A. and JACOBSEN S. B. (1988) The Nd and Sr isotopic evolution of Proterozoic seawater. Geophys. Res. Let. 15, 397400.

DeRry L. A., Keto L. S., Jacobsen S. B., KNOLl A. H., and SwetT K. (1989) Sr isotopic variations in Upper Proterozoic carbonates from Svalbard and East Greenland. Geochim. Cosmochim. Acta 53, 2331-2339.

DerRy L. A., Kaufman A. J., and JaCobSEN S. B. (1990) Controls on sedimentary cycling in the late Proterozoic from $\mathrm{Nd}, \mathrm{Sr}, \mathrm{C}$, and S isotopic data. Geol. Soc. Amer. Prog. 22, A190.

DixON J. (1979) Comments on the Proterozoic stratigraphy of Victoria Island and the Coppermine area. Geol. Surv. Canada Paper 79-1B, pp. 263-267

Gass I. G. (1981) Pan-African (Upper Proterozoic) plate tectonics of the Arabian-Nubian shield. In Precambrian Plate Tectonics (eds. A. KRONER), pp. 387-405. Elsevier.

GolDSTEIN S. J. and JACOBSEN S. B. (1987) The $\mathrm{Nd}$ and $\mathrm{Sr}$ isotope systematics of river water dissolved material: Implications for the source of $\mathrm{Nd}$ and $\mathrm{Sr}$ in seawatcr. Chem. Geol. (Isotope Geosci. Sect.) 66, 245-272.

Grant S. W., KNoll A. H., and Germs G. J. B. (1991) Probable calcified metaphytes in the latest Proterozoic Nama Group, Namibia: Origin, diagenesis, and implications. J. Paleontol. 65, 118.

HARRIS N. B. W., HAWKESWORTH C. J., and RIES A. C. (1984) Crustal evolution in north-east Africa and east Africa from model Nd ages. Nature 309, 773-776.

HEAMAN L. M. and RAINBIRD R. H. (1990) A U-Pb baddeleyite study of Franklin igneous events, Canada. Geol. Assoc. Canada Mineral Assoc. Canada Prog. 15, A55.

HESS J., BENDER M. L., and SCHILling J.-G. (1986) Evolution of the ratio of strontium- 87 to strontium- 86 in seawater from Cretaceous to present. Science 231, 979-984.

Hodell D. A., Mueller P. A., MCKenzie J. A., and MEAD G. A. (1989) Strontium isotope stratigraphy and geochemistry of the late Neogene ocean. Earth Planet. Sci. Lett. 92, 165-178.

JACOBSEN S. B. (1988) Isotopic constraints on crustal growth and recycling. Earth Planet. Sci. Lett. 90, 315-329.

JaCoBsen S. B. and Pimentel-Klose M. R. (1988a) A Nd isotopic study of the Hamersley and Michipicoten banded iron formations: The source of REE and $\mathrm{Fe}$ in Archean oceans. Earth Planet Sci. Lett. 87, 29-44.

Jacobsen S. B. and Pimentel-Klose M. R. (1988b) Nd isotopic variations in Precambrian banded iron formations. Geophys. Res Lett. 15, 393-396.

JAMES H. L. (1983) Distribution of banded iron formation in space and time. In Iron Formations: Facts and Problems (eds. A. F. Trendall and R. C. Mokris), Chap. 12, pp. 471-490. Elsevier.

JEFFERSON C. W. ( 1977) Stromatolites, sedimentology, and stratigraphy of parts of the Amundsen Embayment, N. W. T. Master's thesis, Univ. Western Ontario.

JEFFERSON C. W. (1985) Uppermost Shaler Group and its contact with the Natkusiak basalts, Victoria Island, District of Franklin. Geol. Surv. Canada Paper 85A, pp. 103-110.

Kaufman A. J., Hayes J. M., and Klein C. (1991) Primary and diagenetic controls of isotopic composition of iron-formation carbonates. Geochim. Cosmochim. Acta 54, 3461-3473.

KETO L. S. and JACOBSEN S. B. (1987) Nd and Sr isotopic variations of Early Paleozoic oceans. Earth Planet. Sci. Lett. 84, 27-41.

KETO L. S. and JACOBSEN S. B. (1988) Nd isotopic variations of Phanerozoic paleoceans. Earth Planet. Sci. Lett. 90, 395-410.

KNOLl A. H. and BuTTERFIELD N. J. (1989) New window on Proterozoic life. Nature 337, 602-603.

KNOLl A. H. and SwetT K. (1990) Carbonate deposition during the Late Proterozoic Era: An example from Spitshergen. Amer. J. Sci. 290A, 104-132.
KNOLL A. H. and WALKER J. C. G. (1990) The environmental context of early Metazoan evolution. Geol. Soc. Amer. Prog. 22, A128.

KnOll A. H., Hayes J. M., Kaufman A. J., SwetT K., and LamBERT I. B. (1986) Secular variations in carbon isotope ratios from Upper Proterozoic successions of Svalbard and East Greenland. Nature 321, 832-838.

KOEPNICK R. B., BURKe W. H., DENISON R. E., HETHERINGTON E. A., Nelson H. F., Otto J. B., and Waite L. E. (1985) Construction of the seawater ${ }^{87} \mathrm{Sr} /{ }^{86} \mathrm{Sr}$ curve for the Cenozoic and Cretaceous: Supporting Data. Chem. Geol. (Isot. Geosci. Sect.) 58, $55-81$.

Koepnick R. B., Denison R. E., and Dahl D. A. (1988) The Cenozoic seawater ${ }^{87} \mathrm{Sr} /{ }^{86} \mathrm{Sr}$ curve: Data review and implications for correlation of marine strata. Paleoceanogr. 3, 743-756.

KOEPNiCK R. B., DENISON R. E., BuRke W. H., HETHERINGTON E. A., and DAHL D. A. (1990) Construction of the Triassic and Jurassic portion of the Phanerozoic curve of seawater ${ }^{87} \mathrm{Sr} /{ }^{86} \mathrm{Sr}$. Chem. Geol. (Isot. Geosci. Sect.) 80, 327-349.

KRONER A. (1979) Pan-African mobile belts as evidence for a tectonic regime from intraplate orogeny to plate margin orogeny. In Evolution of the Arahian-Nubian Shield, Vol. 1 (ed. A. M. S. SHANTI), pp. 21-37. Pergamon.

KrONER A., Greiling R., Reischman T., HuSSEIN I. M., Stern R. J., DurR S., Kruger J., and Zimmer M. (1987) Pan-African crustal evolution in the Nubian segment of Northeast Africa. In Precambrian Plate Tectonics (eds. A. KRONER), pp. 235-257. Elsevier.

MCWILliams M. O. (1981) Paleomagnetism and Precambrian tectonic evolution of Gondwana. In Precambrian Plate Tectonics (eds. A. KRONER), pp. 649-687. Elsevier.

Pallister J. S., Stacey J. S., Fischer L. B., and Premo W. R. (1987) Arabian Shield ophiolites and Late Proterozoic microplate accretion. Geology 15, 320-323.

Palmer M. R. and EDMOND J. M. (1989) The Strontium isotope budget of the ocean. Earth Planet. Sci. Lett. 92, 11-26.

Palmer M. R. and Elderfield H. (1985) Sr isotope composition of seawater over the past $75 \mathrm{Myr}$. Nature 314, 526-528.

PAPANASTASSIOU D. A. and WASSER burG G. J. ( 1969) Initial strontium isotopic abundances and the resolution of small time differences in the formation of planetary objects. Earth Planet. Sci. Lett. $5,361-376$.

PARK J. K. and AITKEN J. D. (1986) Paleomagnetism of the Katherine Group in the Mackenzie Mountains: Implications for postGrenville (Hadrynian ) apparent polar wander. Canadian J. Earth Sci. 23, 308-323.

PIPER J. D. A. (1982) The Precambrian palaeomagnetic record: The case for the Proterozoic Supercontinent. Earth Planet. Sci. Lett. $59,61-89$.

PORADA H. (1989) Pan-African rifting and orogenesis in Southern to Equatorial $\Lambda$ frica and eastern Brazil. Precambrian Res. 44, 103136.

Ries A. C., Shackleton R. M., and Dawoud A. S. (1985) Geochronology, geochemistry, and tectonics of the NE Bayuda desert, $N$ Sudan: Implications for the western margin of the Late Proterozoic fold belt of NE Africa. Precambrian Res. 30, 43-62.

ReYmo M. E., Ruduiman W. F., and Froelich P. N. (1988) Influence of Late Cenozoic mountain building on ocean geochemical cycles. Geology 16, 649-653.

SHACKIETON R. M. (1986) Precambrian collision tectonics in Africa. In Collision Tectonics (eds. M. P. CowARD and A. C. RIES); Geol Soc. Lond. Spec. Pub. 19, pp. 329-349.

SHAW H. F. and WASSERBURG G. J. (1985) Sm-Nd in marine carbonates and phosphates: Implications for $\mathrm{Nd}$ isotopes in seawater and crustal ages. Geochim. Cosmochim. Acta 49, 503-518.

SLEEP N. H. (1971) Thermal effects of the formation of Atlantic continental margins by continental break-up. Geophys. J. Royal Astron. Soc. 4, 325-350.

SPOONER E. T. C. (1976) The strontium isotopic composition of seawater and seawater-oceanic crust interaction. Earth Planet. Sci. Lett. 36, 359-362.

SwetT K. and KNOLL A. H. (1989) Marine pisolites from Upper Proterozoic carbonates of East Greenland and Spitsbergen. Sedimentology 36, 75-93.

TUCKER M. (1982) Sedimentation of organic-rich limestones in the 
Late Precambrian of southern Norway. Precambrian Res. 22, 295315.

VEIZER J. (1985) Carbonates and ancient oceans: Isotopic and chemical record on time scales of $10^{7}-10^{9}$ years. In The Carbon Cycle and Atmospheric $\mathrm{CO}_{2}$ : Natural Variations Archean to Present (eds. E. T. SUNDQUIST and W. S. BROECKER ), pp. 595-601. Amer. Geophys. Union.

Veizer J., COMPSTON W., Clauer N., and SCHIDlowSKi M. (1983) ${ }^{87} \mathrm{Sr} /{ }^{86} \mathrm{Sr}$ in Late Proterozoic carbonates: Evidence for a "mantle event" at $900 \mathrm{Ma}$ ago. Geochim. Cosmochim. Acta 47, 295-302.

WANLESS R. K. and LOVERIDGE W. D. (1972) Rubidium-strontium isochron age studies, report 1. Geol. Surv. Canada Paper 72-23.
YouNG G. ( 1981 ) The Amundsen Embayment, N. W. T.: relevance to the Upper Proterozoic evolution of North America. Geol. Surv. Canada Paper 81-10, pp. 203-218.

Young G. and JeFFERSON C. W. (1975) Late Precambrian shallow water deposits, banks, and Victoria islands, Arctic Archipelago. Canadian J. Earth Sci. 12, 1734-1748.

YouNG G. and LoNG D. G. F. (1977) Carbonate sedimentation in a Late Precambrian shelf sea, Victoria Island, Arctic Archipelago. J. Sediment. Petrol. 47, 943-955.

Young G., Jefrerson C. W., Delaney G. D., and Yeo G. M. (1979) Middle and Late Proterozoic evolution of the northern Canadian Cordillera and Shield. Geology 7, 329-330. 